\title{
Grassland Restoration at a Graded Ski Slope: Effects of Propagation Material and Fertilisation on Plant Cover and Vegetation
}

\author{
Michele Scotton
}

Citation: Scotton, M. Grassland Restoration at a Graded Ski Slope: Effects of Propagation Material and Fertilisation on Plant Cover and Vegetation. Agriculture 2021, 11, 381 https://doi.org/10.3390/ agriculture11050381

Academic Editor: Danilo Scordia

Received: 10 March 2021

Accepted: 19 April 2021

Published: 23 April 2021

Publisher's Note: MDPI stays neutral with regard to jurisdictional claims in published maps and institutional affiliations.

Copyright: (C) 2021 by the author. Licensee MDPI, Basel, Switzerland. This article is an open access article distributed under the terms and conditions of the Creative Commons Attribution (CC BY) license (https:// creativecommons.org/licenses/by/ $4.0 /)$.
Department of Agronomy, Food, Natural Resources, Animals and Environment, University of Padova, Viale dell’Università 16, 35020 Legnaro, PD, Italy; michele.scotton@unipd.it

\begin{abstract}
The increasing anthropisation of mountain regions is a cause of soil degradation, which needs to be addressed. Conventional methods of ski slope revegetation often fail to stabilise the soil and recover natural vegetation. To test alternative methods to create a persistent, biodiversityfriendly plant cover, different sowing (site-adapted native propagation materials vs. forage cultivars vs. no sowing) and fertilisation treatments were compared over nine years at a graded ski slope. Because of the gravelly soil, the ninth-year plant cover was only $65 \%$, which was sufficient to prevent erosion. All native propagation materials were equally efficient at recreating a semi-natural grassland. Except for Festuca rubra, the forage cultivars did not persist. However, native volunteer species from close natural ecosystems efficiently colonised plots sown with forage cultivars and plots that were not sown. This resulted in a lower plant cover but a high similarity to the surrounding vegetation. Fertilisation had a positive but transient effect on plant cover and a little negative effect on species richness. High-altitude sites with gravelly soils should be revegetated with native propagation materials. Using forage cultivars can attain a persistent plant cover only if the sown non-persistent cultivars are replaced by the species arriving from nearby surrounding vegetation.
\end{abstract}

Keywords: cultivar; grading; revegetation; semi-natural grassland; wild harvesting

\section{Introduction}

The development of the mountain tourist industry in recent decades has led to the construction of many impacting infrastructures [1]. Ski slopes are among those with the highest environmental incidence, as they involve extensive surfaces with high-quality habitats [2], often included in natural protection areas.

The standard method of ski slope construction is regrading and revegetating with seed mixtures of forage cultivars [3]. After removal of the woody species layer, the soil, often including underlying rocks, is worked with heavy machinery to eliminate bumps and hollows and obtain a smoother surface [4]. With regrading, the vegetation present at the site is destroyed. Vascular plants and soil micro-organisms are mostly buried under a deep soil layer, where they cannot survive [2]. The soil resulting from regrading is shallow, gravelly, and poor in organic matter, nutrient content, and water holding capacity $[4,5]$. At sites with a very cold climate, the spontaneous ecosystem recovery through volunteer species colonisation occurs very slowly on such raw soils, especially when the natural vegetation acting as a possible seed source is faraway [6,7].

In addition to being inexpensive, forage cultivars have high seed germinability and rapid seedling growth and therefore create a rapid and dense plant cover [8]. However, they also cause significant environmental problems. At high altitudes, the plant cover obtained is poorly persistent [2], as the forage cultivars that are typical of mild and fertile environments [9] suffer from the cold climate and infertile soils [10,11]. The poor plant cover persistence makes repeated sowing necessary to maintain its capacity to protect the soil against erosion [12]. In more favourable climates and soils, the main environmental 
problem is that the plant cover from sowing of cultivars represents an artificial vegetation that is likely to delay [13] or prevent $[4,14]$ the recovery of natural ecosystems. This last unfavourable development was observed especially when the seed mixture included Festuca rubra, a species with a particularly high adaptability and competitivity [15]. Along with negative impacts, a positive effect was also sometimes observed, due to the cultivar "nurse" effect in favour of volunteer species [10].

Along with cultivar seed sowing, NPK fertilisers are normally applied to favour soil nutrient accumulation [16] in the infertile raw soils of graded ski slopes. The desired effect is to accelerate the achievement of an effective anti-erosion plant cover. Fertilisation is often repeated to support the persistence of the sown nutrient-demanding cultivars [11]. However, NPK fertilisation was found to induce a strong grass dominance, thereby decreasing the number of native species colonising the site and delaying the recovery of natural vegetation [5].

Ski slope grading is currently a matter of great concern because of its impact on wide areas in mountain landscapes, which safeguard most of the natural habitats remaining in highly urbanised areas. Therefore, many studies have been undertaken in the last few decades to improve the techniques of ski slope construction and management.

Topsoil storage and re-use was found to be an effective method to facilitate the ecosystem recovery after grading [17]. Before grading, the fertile topsoil is removed with an excavator and piled close to the ski run. The infertile subsoil is then worked upon to obtain a smooth ground, over which the stored topsoil is lastly spread $[9,18]$. An alternative way to reduce impacts is clearing instead of grading [4], whereby only above-ground obstacles (shrubs and trees, rocks, among others) are removed, and the topsoil, including the herbaceous vegetation, is left untouched.

Instead of using forage cultivars, seed sowing of site-adapted native species has been proposed as a method to create a persistent plant cover and protect mountain biodiversity [2]. Seeds of native species are collected from natural habitats, propagated in agricultural cultivation, and used in the same biogeographic region of collection [19]. The restricted geographical range of permitted seed utilisation makes the seed costs much higher than in the case of forage cultivars. Therefore, most species suitable for high-altitude environments are unavailable in seed markets. An alternative is to collect seeds directly from (semi-)natural grasslands (wild harvesting) in the forms of seed-rich fresh or dry hay and seed-stripped or threshed hay flowers [20]. Many experiments have demonstrated the effectiveness of sowing native seeds from agricultural propagation (e.g., [12,21]). Wildharvested seeds were found to perform well at low altitudes (e.g., [22]); however, to our knowledge, their effectiveness and the differences among the wild harvesting methods in terms of restoration results have not yet been investigated at high-altitude sites.

Despite the recommendations mentioned in technical handbooks and public regulations (e.g., [18,23]), most ski slope constructions have not adopted and continue to not adopt the suggested low-impact methods. The critical issue of ecosystem conservation in the infrastructural works in mountain environments is therefore still open.

Therefore, the research reported here aimed at investigating the potential of using wild-harvested seeds to overcome the two main problems of high-altitude revegetation: the short persistence of the plant cover of forage cultivars and its failing development to natural vegetation. The specific aims were:

- To test different types of wild-harvested propagation material and compare them to seeds of forage cultivars for plant cover persistence and species composition. The hypothesis was that the cover obtained with different wild-harvested materials would have different species composition and persist longer than those generated by forage cultivars.

- To test different fertilisation timing and frequency to improve the plant cover. The hypothesis was that more frequent fertilisation would accelerate the establishment of plant cover and the induced higher cover would persist even after the fertilisation cessation. 


\section{Materials and Methods}

\subsection{The Experimental Site}

The experimental site was located at a ski run in the municipality of Primiero San Martino (north-eastern Italy; $46.247597^{\circ} \mathrm{N}, 11.765282^{\circ} \mathrm{E}$ ), approximately $2095 \mathrm{~m}$ a.s.1. (low-alpine belt) in a mountain pasture landscape. At the nearby meteorological station of the Rolle Pass (2004 m a.s.l.), the annual mean temperature and rainfall were $3.4{ }^{\circ} \mathrm{C}$ and $1334 \mathrm{~mm}$, respectively, with the Alpine Köppen-Geiger climate [24]. The monthly temperature and rainfall recorded in the experimental years and used in the data analysis are shown in Table S1. The parent rock was quarzitic phyllite. In 2001, the ski run was machine-graded without topsoil storage and re-use.

In 2002, a grassland restoration experiment was established in a ski-run unvegetated sector with an average inclination of $15.4^{\circ}$ and a southern aspect. The soil $(0-10 \mathrm{~cm}$ layer $)$ had $66 \%$ gravel content. The fine earth had $0.03 \%$ organic matter content, a sandy loam texture, strongly acidic reaction, and poor in total nitrogen, plant-available phosphorous and exchangeable potassium (Table S2).

The experimental site was surrounded by 15-20 unvegetated strips and, beyond this, by extensive semi-natural vegetation referable as Nardion strictae grasslands and Rhododendro-Vaccinion heaths (vegetation units according to Theurillat et al. [25]). In $25 \mathrm{~m}^{2}$ plots, the Nardion grasslands contained an average of 5.5 grasses, 17.5 forbs, and 6 shrubs, with the grass Nardus stricta being the main species. The Rhododendro-Vaccinion heath included 5 grasses, 18 forbs, and 6 shrubs, with the main species being the shrubs Juniperus communis and Rhododendron ferrugineum (Table S3: species identification, names and authorities according to Pignatti [26]). The total number of species surveyed in the surrounding vegetation was 72 . The soils had similar sandy loam texture, organic matter content, and strongly acidic reaction (Table S2).

\subsection{The Experiment}

The restoration experiment was organised as a split plot design with two experimental factors (propagation material and fertilisation). Three $10 \mathrm{~m} \times 30 \mathrm{~m}$ blocks (replicates) were divided into six $5 \mathrm{~m} \times 10 \mathrm{~m}$ main plots, and the main plots were divided into four $5 \mathrm{~m} \times 2.5 \mathrm{~m}\left(12.5 \mathrm{~m}^{2}\right)$ split plots.

The main plot factor was the type of propagation material with six levels (Table 1). Four propagation materials were wild-harvested from a donor semi-natural grassland at the time of optimal grass seed maturation (14 August 2002) and sown on the same day in the experimental plots. The materials were: green hay, high sowing rate (donor/receptor site area ratio 2:1, G) and low rate (area ratio 1:1, g), seed-stripped hay flower (area ratio 2:1, S), and dry hay (area ratio 2:1, D). The donor grassland was located $14 \mathrm{~km}$ from the experiment, at $1895 \mathrm{~m}$ a.s.l. The vegetation was a Nardo-Agrostion grassland with 45 species recorded from $25 \mathrm{~m}^{2}$ plots, 66 species on the whole meadow surface, and grass and forb percent abundances of $64 \%$ and $36 \%$, respectively (species composition in Table S3, samples NAa-NAc). The vegetation had many species in common with the Nardion grassland receptor site. Based on samples collected at harvesting, the propagation materials contained mature seeds of 27 species with sowing rates of 12,414, 6207, 10,511, and 6932 mature seeds per $\mathrm{m}^{2}$ in $\mathrm{G}, \mathrm{g}$, S, and D, respectively (other details on harvesting in Scotton et al. [27]). The fifth treatment was sowing a seed mixture of forage cultivars (C) (11 species: 7 grasses, Dactylis glomerata, Festuca ovina, Festuca pratensis, Festuca rubra, Lolium perenne, Phleum pratense, and Poa pratensis; 4 forbs, Medicago lupulina, Medicago sativa, Trifolium hybridum, and Trifolium repens; sowing rate, 40,777 seeds per $\mathrm{m}^{2}$ ). Its composition (see Table S3, sample Mix) included species very commonly used in the past decades to revegetate bare surfaces in European mountains and was very similar to mixtures analysed or used in other revegetation studies (see, e.g., [10]). The sixth treatment was of no sowing $(\mathrm{N})$. To improve seed germination and have an identical amount of mulching material in all treatments, wheat straw was spread on the sown plots, so that the total dry weight of straw mulching plus propagation material was equal to $500 \mathrm{~g} \mathrm{~m}^{-2}$ [28]. 
Table 1. Experimental factors and corresponding levels of the ski slope grassland restoration experiment.

\begin{tabular}{|c|c|c|c|c|}
\hline \multirow[b]{2}{*}{ Propagation Material } & \multicolumn{3}{|c|}{ Experimental Factor } & \\
\hline & & & Fertilisation $^{4}$ & \\
\hline Level (code) & Area ratio $^{3}$ & Sowing rate (no seed $\mathrm{m}^{-2}$ ) & Level (code) & $\begin{array}{l}\text { Fertilisation year } \\
\text { after sowing year }\end{array}$ \\
\hline Green hay, high rate $(G)^{1}$ & $2: 1$ & 12,414 & Continuous fertilisation (CF) & $1,2,3$, and 4 \\
\hline Green hay, low rate $(\mathrm{g})^{1}$ & $1: 1$ & 6207 & Initial fertilisation (IF) & 1 , and 2 \\
\hline Seed-stripped hay flower (S) ${ }^{1}$ & $2: 1$ & 10,511 & Delayed fertilisation (DF) & 3 , and 4 \\
\hline Dray hay (D) ${ }^{1}$ & $2: 1$ & 6932 & No fertilisation (NF) & - \\
\hline Mixture forage cultivars (C) ${ }^{2}$ & - & 40,777 & - & - \\
\hline No sowing $(\mathrm{N})$ & - & 0 & - & - \\
\hline
\end{tabular}

Legend. ${ }^{1}$ Propagation materials harvested at a semi-natural grassland (species composition in Table S3). ${ }^{2}$ Species composition in Table S3. ${ }^{3}$ Area ratio, donor/receptor site area ratio. ${ }^{4}$ Fertilisation rate: $60,26.2$, and $49.8 \mathrm{~kg}$ per ha of N, P, and K, respectively, with N added in nitric (50\%) and ammoniacal (50\%) forms.

The split plot factor was the fertilisation timing and frequency after the sowing year (Table 1), with four levels: years 1 to 4 (continuous fertilisation, CF), years 1 and 2 (initial fertilisation, IF), years 3 and 4 (delayed fertilisation, DF), and no fertilisation (NF). In the propagation material treatments $\mathrm{C}$ and $\mathrm{N}$, only $\mathrm{CF}$ and $\mathrm{NF}$ were applied. The yearly fertilisation rate was $60,26.2$, and $49.8 \mathrm{~kg}$ per ha of N, P, and K, respectively, with $\mathrm{N}$ added in nitric (50\%) and ammoniacal (50\%) forms. Independent of the fertilisation treatment, plots were fertilised at sowing with the same amount as above.

The total number of treatments in the experimental design was 20 (four propagation materials $\times$ four fertilisation levels plus two propagation materials $\times$ two fertilisation levels). In the years after sowing, the experimental area was managed in the same way as the surrounding ski run areas, that is, it was grazed at a low stocking rate by the cattle of a nearby summer farm and run through by the vehicles of the ski resort workers.

After sowing, the experiment was surveyed six times (2003, 2005, 2007, and 20092011) in August for the following five ground cover traits that were visually estimated as percent values: stones larger than $5 \mathrm{~cm}$, stones smaller than $5 \mathrm{~cm}$ or fine earth, litter (straw mulch or dead plant materials), mosses and lichens (biological soil crust: BSC), and vegetation (vascular plants) cover. In addition, a list of all vascular plants, identified according to Pignatti [26], was compiled for each plot, and the corresponding percent cover was estimated.

\subsection{Univariate Analyses on Ground Cover Traits, Species Transfer, and Richness}

Univariate methods were used to characterise the effects of treatments and time on important ground cover traits, species transfer, and richness.

All field-assessed ground cover traits were considered along with the following seven traits calculated for each plot: total grass and forb cover, total species number, number of species from the donor grassland (species D), from both the donor grassland and the receptor site Nardion grassland (species DRn), from other receptor site vegetation (species Ro), and from the cultivar seed mixture (species $C$ ). Species were allocated to the different provenance groups based on the donor and receptor site surveys where they had been recorded from. For each plot and survey, three similarity indices were calculated: the Jaccard indices ([29]: calculated from presence-absence data) relative to the donor site Nardo-Agrostion and the receptor site Nardion strictae grasslands, and the similarity ratio ([30]: calculated from cover data), relative to the donor grassland.

For the above 15 traits, linear mixed models according to a split-plot design and a repeated measure approach were used to assess the effect of three fixed factors (propagation material, fertilisation, and surveyed year) and their interactions. Before the analysis, the data were checked for homoscedasticity and normality and, if needed, log- or arcsinetransformed to meet the parametric analysis assumptions. In the model calculation, a plot identifier was used to define the subject effect in the repeated measure analysis. In case of a significant factor effect, the among-means differences were tested using the Tukey 
multiple comparison adjustment. According to Quinn and Kenough [31], as the N and $\mathrm{C}$ propagation materials had only two fertilisation levels (CF and NF), two models were calculated for each trait with the first including six propagation materials but only two fertilisation levels ( $\mathrm{CF}$ and $\mathrm{NF}$ ), and the second including only four propagation materials $(G, g, S$, and D), but all fertilisation levels.

In a further analysis, species transfer from the donor and receptor sites was analysed. The donor site species transfer rate was calculated as the percentage of species found on any experimental plot relative to all donor site species (absolute transfer rate) or to the species present as mature seeds at harvest (relative transfer rate) [32]. The absolute transfer rate was also calculated for the receptor site species.

Transfer rates were also calculated for the individual experimental treatments. As the number of species present in a specific area depends strongly on the area size (species-area curve, [33]), calculating transfer rates for each split plot was not appropriate, as its size $\left(12.5 \mathrm{~m}^{2}\right)$ was half that of the sampling area of the donor and receptor site vegetation $\left(25 \mathrm{~m}^{2}\right)$. Therefore, the total number of species found in the CF and NF split plots (total area $25 \mathrm{~m}^{2}$ ) was calculated for the G, S, g, and D sowing treatments, and the mean number of species found in the CF and NF plots of the N and C sowing treatments was calculated. In this way, it was possible to calculate transfer rates based on the same area size for all six propagation materials. The differences in transfer rates were analysed in a two-way ANOVA in two variants: with factors year and propagation material (six levels: G, S, g, $\mathrm{D}, \mathrm{N}$, and $\mathrm{C}$ ) and with factors year and origin of propagation material (three levels: from donor grassland, N, and C). In both analyses, the data were checked for homoscedasticity and normality, and if necessary, square-root transformed, and submitted to linear mixed models under the same repeated measure approach as above.

To check if the abundance of individual species affected the species diversity, linear regressions were calculated between the main grass cover (Festuca rubra and Agrostis tenuis) or the total grass cover in each treatment and the corresponding mean species number. The calculations were performed separately for three homogeneous propagation material types (from donor grassland, C, and N), separately for each year and for all years together. Regression residuals were checked for normality and homoscedasticity using the ShapiroWilk and White tests, respectively. The intercept and slope homogeneity of the significant regressions obtained for the individual years were checked by using a general linear model for the species number, in which a dummy variable defining the year, the grass cover, and the interaction grass cover $\times$ year were input as independent variables and the species number was input as a dependent variable ([34], Usage Note 24177).

To check the possible influence of the year meteorological variables on the experiment results, linear regressions were calculated between the above-described individual traits and the monthly, seasonal and yearly total rainfall and mean temperature.

Univariate analyses were performed with SAS/STAT software version 9 for Windows [34] with proc MIXED for linear mixed models and proc GLM for ordinary regression and testing homogeneity of the regression intercepts and slopes.

\subsection{Multivariate Analyses on Vegetation}

The treatment and time effects on the vegetation were analysed with the multivariate methods of redundancy (RDA) and principal component analysis (PCA), performed on both the presence-absence and the cover data. Linear ordinations were chosen instead of unimodal methods, as the maximum gradient length of a detrended correspondence analysis with detrending by segment was less than three [35].

According to a multivariate repeated-measure design [35], RDA was used in five separate analyses to test the effect of treatment, propagation material, fertilisation, year, and the interaction treatment $\times$ year. The ordination was performed using a dataset including all six propagation materials but only the CF and NF fertilisation levels. In the analyses, dummy variables describing the factor levels and block and plot identifiers were input as explanatory variables or covariables depending on the effect to be tested. The 
trace value calculated for each RDA represented the variability proportion explained by the tested effect. To calculate the null hypothesis probability, the F-ratio of all canonical axes $\left(\mathrm{F}_{\text {trace }}\right)$ was used as a test statistic, and a Monte Carlo test with 1000 permutations was performed. As with the univariate models, RDA analyses were performed for the two data sets including six propagation material levels but two fertilisation levels and four propagation material levels but all fertilisation levels. As the outcomes were similar, only the first analysis results are reported.

The temporal trend of vegetation was analysed with PCA, in which all 20 treatments were considered together, as unconstrained methods do not require a balanced design. The mean species composition was calculated for three replicates of each treatment. The data set used in the PCA included 120 samples (20 treatments $\times$ six surveying years). In addition to the treatment surveys, botanical surveys of the donor grassland, the receptor site vegetation, and the $C$ mixture were input. In this way, the PCA results could also represent the relationship between the experimental treatments and the donor and receptor site vegetation.

In both RDA and PCA, data were centred by species. Cover data were square-root transformed to reduce the weight of the more abundant species [35] and standardised by sample to eliminate the effect of the low vegetation cover in the first years after sowing. To facilitate the interpretation of the ordination results, a cluster analysis of the same data table used in PCA was performed, and the results are shown in Table S3.

Multivariate analyses were performed with Canoco [35] version 4.5 for RDA and PCA, and MULVA-4 [36] for cluster analysis.

\section{Results}

\subsection{Ground Cover}

The multi-year average vascular plant cover was $62.2 \%$, and the uncovered ground cover was $37.8 \%$ (Table 2). No clear evidence of erosion was found during the survey in any treatment.

Table 2. Effects of six propagation materials and two fertilisation treatments on the main traits of a ski slope grassland restoration experiment.

\begin{tabular}{|c|c|c|c|c|c|c|c|c|c|c|c|c|c|c|}
\hline \multirow[b]{2}{*}{ Propagation Material $^{1}$} & \multicolumn{8}{|c|}{ Treatment Means } & \multicolumn{6}{|c|}{ Factor Main and Interaction Effect ${ }^{3}$} \\
\hline & G & $\mathrm{S}$ & $\mathrm{g}$ & $\mathbf{D}$ & $\mathbf{N}$ & $\mathrm{C}$ & Mean & Mean & $\mathbf{P M}$ & $\mathbf{F}$ & PMxF & $\mathrm{Y}$ & PMxY & $\mathbf{F} \times \mathbf{Y}$ \\
\hline Fertilisation $^{2}$ & Mean & Mean & Mean & Mean & Mean & Mean & $\mathrm{CF}$ & NF & & & & & & \\
\hline Cover stones diameter $>5 \mathrm{~cm}(\%)$ & 13.1 & 15.2 & 10.8 & 11.3 & 15.8 & 13.7 & $11.9 \mathrm{~b}$ & $14.8 \mathrm{a}$ & ns & $* * *$ & ** & * & $* * *$ & ns \\
\hline Cover fine earth + stones diam. $<5 \mathrm{~cm}(\%)$ & 13.20 & 13.10 & 17.20 & 13.30 & 23.50 & 16.90 & $12.2 b$ & 19.a & ns & $* * *$ & $* * *$ & $* * *$ & $*$ & $* * *$ \\
\hline Cover litter $(\%)$ & 2.97 & 2.12 & 0.35 & 1.79 & 0.30 & 0.38 & 1.8 & 2.2 & ns & ns & * & $* * *$ & $* * *$ & ns \\
\hline Cover biological soil crust (\%) & 5.7 & 5.6 & 5.5 & 6.1 & 9.6 & 9.2 & $6.46 \mathrm{~b}$ & $7.40 \mathrm{a}$ & ns & $* * *$ & $* * *$ & $* * *$ & $* * *$ & ns \\
\hline Cover vascular plants (\%) & $65 . a$ & $64 . \mathrm{a}$ & $66.1 \mathrm{a}$ & $67.4 \mathrm{a}$ & $50.9 \mathrm{~b}$ & $59.8 \mathrm{ab}$ & $67.7 \mathrm{a}$ & $56.7 \mathrm{~b}$ & $* *$ & $* * *$ & $* * *$ & $* * *$ & $* * *$ & $* * *$ \\
\hline Cover grasses $(\%)$ & $56.1 \mathrm{a}$ & $56.8 \mathrm{a}$ & $56.1 \mathrm{a}$ & $58.3 a$ & $41.6 \mathrm{~b}$ & $50.3 a$ & $58.6 a$ & $47.7 \mathrm{~b}$ & $* * *$ & $* * *$ & $* * *$ & $* * *$ & $* * *$ & $* * *$ \\
\hline Cover forbs $(\%)$ & 8.9 & 7.2 & 10.0 & 9.2 & 9.4 & 9.5 & 9.1 & 9.0 & ns & ns & $* * *$ & $* * *$ & $* *$ & ns \\
\hline No. species total & 18.7 & 21.0 & 19.3 & 21.9 & 23.0 & 21.2 & $20.1 b$ & $21.6 a$ & ns & $* * *$ & $* * *$ & $* * *$ & $* * *$ & ns \\
\hline No. species from donor grassland & $4.3 \mathrm{abc}$ & $3.7 \mathrm{abc}$ & $4.4 \mathrm{ab}$ & $5.0 \mathrm{a}$ & $3.7 \mathrm{abc}$ & $2.8 \mathrm{c}$ & 3.9 & 4.1 & $*$ & ns & $*$ & $* * *$ & ns & ns \\
\hline No. sp. from donor and Nardion grassl. & $10.2 \mathrm{a}$ & $10.7 \mathrm{a}$ & $10.5 \mathrm{a}$ & $11.4 \mathrm{a}$ & $9.1 \mathrm{a}$ & $6.8 b$ & $9.2 b$ & $10.3 a$ & $* * *$ & $* * *$ & $* * *$ & $* * *$ & ns & ns \\
\hline No. species from surrounding & $4.2 \mathrm{c}$ & $6.7 \mathrm{abc}$ & $4.3 c$ & $5.5 \mathrm{abc}$ & $10.1 \mathrm{a}$ & $8.7 \mathrm{ab}$ & 6.4 & 6.7 & $* *$ & ns & $* * *$ & $* * *$ & $* * *$ & ns \\
\hline No. species from comm. seed mixture & $0 \mathrm{~b}$ & $0 \mathrm{~b}$ & $\mathrm{Ob}$ & $0 \mathrm{~b}$ & $0.14 \mathrm{~b}$ & $2.89 a$ & 0.53 & 0.49 & $* * *$ & ns & * & $* *$ & $* * *$ & $*$ \\
\hline Van der Maarel coeff. vs. donor grassl. & 0.5 & 0.4 & 0.3 & 0.5 & 0.3 & 0.3 & 0.4 & 0.4 & ns & ns & 0.001 & $* * *$ & $* * *$ & ns \\
\hline Jaccard coeff. vs. donor grassland & $0.29 b$ & $0.29 b$ & $0.30 \mathrm{ab}$ & $0.34 \mathrm{a}$ & $0.24 \mathrm{c}$ & $0.22 \mathrm{c}$ & 0.28 & 0.28 & $* * *$ & ns & $* * *$ & $* * *$ & ns & ns \\
\hline Jaccard coeff. vs. Nardion grassland & 0.23 & 0.34 & 0.23 & 0.29 & 0.33 & 0.35 & 0.29 & 0.30 & ns & ns & $* *$ & $* * *$ & $* * *$ & ns \\
\hline
\end{tabular}

${ }^{1} \mathrm{G}$ and g, green hay, high and low sowing rate, respectively; S, seed stripping; $\mathrm{D}$, dry hay; $\mathrm{N}$, not sown; C, cultivar seed mixture. ${ }^{2} \mathrm{CF}$ and $\mathrm{NF}$, continuous and no fertilisation, respectively. ${ }^{3} \mathrm{PM}$, propagation material; F, Fertilisation; Y, year; ns, not significant; ${ }^{*} 0.05 \geq p>0.01$; ${ }^{* *} 0.01 \geq p>0.001 ;{ }^{* * *} 0.001 \geq p$. Means with common letters do not differ at $p \leq 0.05$.

Fertilisation was the treatment factor with the highest effect on the ground cover traits. It increased the vascular plant cover by approximately $10.9 \%$ and reduced stones, fine earth, and BSC by the same overall amount. In comparison with NF, CF, IF, and DF had the highest, intermediate, and lowest positive effects on the vascular plant growth, respectively (Table S4). 
The sowing treatments influenced the ground cover less than fertilisation. No difference was found among the treatments with seed sowing (donor grassland materials and C), and plant cover was significantly lower in the $\mathrm{N}$ treatment (Table 2).

Analysis of the cover time pattern showed that vascular plant cover was approximately $50 \%$ in the first year after sowing (Figure 1a and Supplementary Figure S1), reached a maximum $(71 \%)$ in the third year and decreased, even if not significantly, to $64-68 \%$ from the fifth year onwards, after fertilisation cessation. Grasses were almost exclusive in the first year and were partially replaced by forbs from the third year onwards. Even in the last survey year, the ground remained partially uncovered (approximately 35\%) by vascular plants. However, from the fifth year onwards, stones and bare soil were largely occupied by the BSC (Figure 1a). In the $\mathrm{N}$ treatment, the vascular plant cover was relatively low in the first four years but attained the same levels as the other treatments from the fifth year onwards (Supplementary Figure S1). Fertilisation had a significant and positive effect during the years when it was applied. Subsequently, the effect persisted, but was less marked and not significant any more (Figure 2). This pattern was particularly evident in the $\mathrm{C}$ treatment (Figure S1).
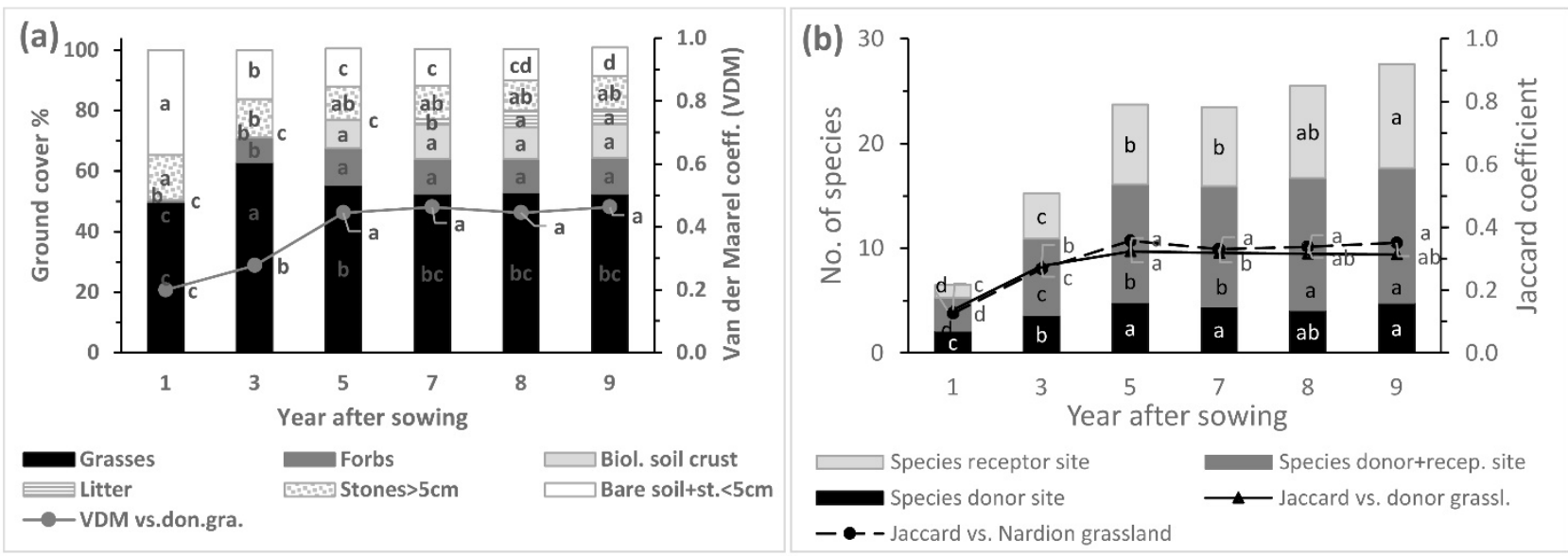

Figure 1. Time pattern of ground cover (a) and species number $(\mathbf{b})$ at a ski slope grassland restoration experiment. Data are averages of twelve treatments (two fertilisation treatments $\times$ six propagation materials). VDM and Jaccard are the van der Maarel and Jaccard similarity indices, respectively. Letters show results of among-year comparisons.

\subsection{Species Number}

A total of 101 species were found within the experimental area during the nine-year survey period. The average number of species per plot was 21 (Table 2). Fertilisation significantly decreased the number of species, but the negative effect size ( -1.5 species) was relatively low compared to the positive effect on the ground cover.

The type of propagation material did not influence the total species number but significantly affected the same trait within each species category (Table 2). Treatments with donor grassland materials had more D and DRn species but fewer Ro and C species. Treatment $C$ contained the highest number of $C$ species. Despite this trend, which depended on the specific propagation material, a high number of species in each plot arrived from external areas (other plots or vegetation surrounding the experiment).

The species number was initially low, increased rapidly until the fifth year, and less rapidly subsequently (Figure 1b). The species established were mainly D and DRn species in the initial years and Ro species in the last few years. Even if not very marked in the all-years average (see above), the negative effect of fertilisation increased until the fifth year and remained similar after fertilisation cessation (Figure 2). In addition, in the initial years, treatments with donor grassland materials had a higher number of species than $\mathrm{N}$ and $C$ treatments but had lower number in the last year (compare Figure 2 with Figure S2). The average species composition of the restored plots was equally similar to the donor grassland and the Nardion receptor site grassland (Table 2). However, the values of the 
Jaccard index calculated versus the Nardion grassland continued to increase in the last few surveyed years as well, especially in the $\mathrm{N}$ and $\mathrm{C}$ treatments (ninth year values $0.42 \mathrm{vs}$. 0.32 in the $G, S, g$, and D treatments).

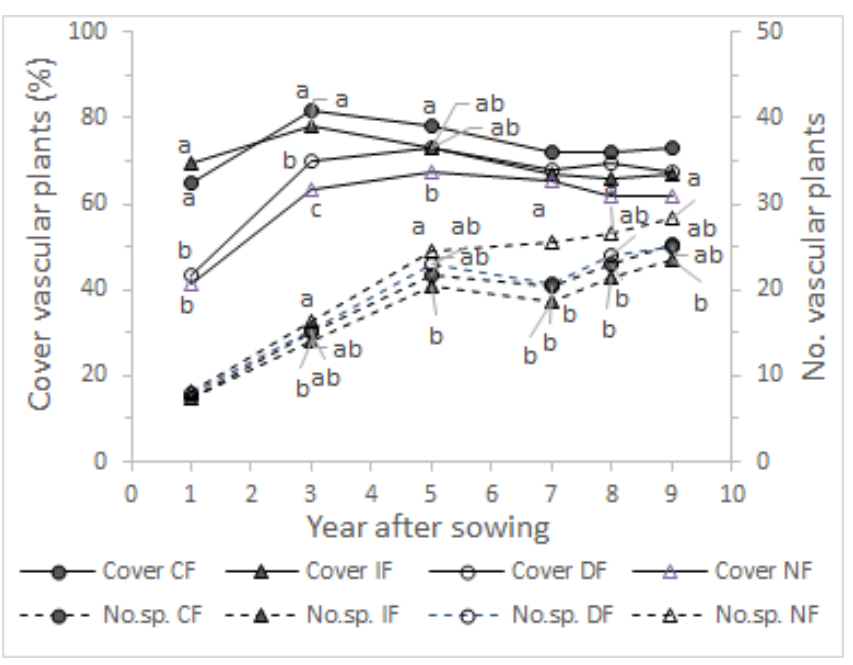

Figure 2. Time pattern of plant cover and species number at a ski slope grassland restoration experiment in four fertilisation treatments (values are averages of four propagation materials from a Nardo-Agrostion donor grassland). Letters show results of among-fertilisation comparisons within each year. Means with common letters do not differ at $p \leq 0.05$. Missing letters mean that fertilisation effect was not significant. CF, IF, DF, and NF mean continuous, initial, delayed and no fertilisation, respectively.

The total number of species established in the treatments with donor grassland materials was negatively influenced by the grass cover. The effect was significant for all grasses, especially for Festuca rubra (Figure 3) but not for Agrostis tenuis. The influence was obvious from the fifth year after sowing, but not in the previous years when the grass cover was still low. As the individual year linear regressions did not differ by constant and slope, a unique regression was calculated ( $\mathrm{Y}=-0.21+30 ; R^{2}=0.21, p<0.001$, Figure $\left.\mathrm{S} 2\right)$. In the N and $C$ treatments, no relationship was found between grass cover and species number.
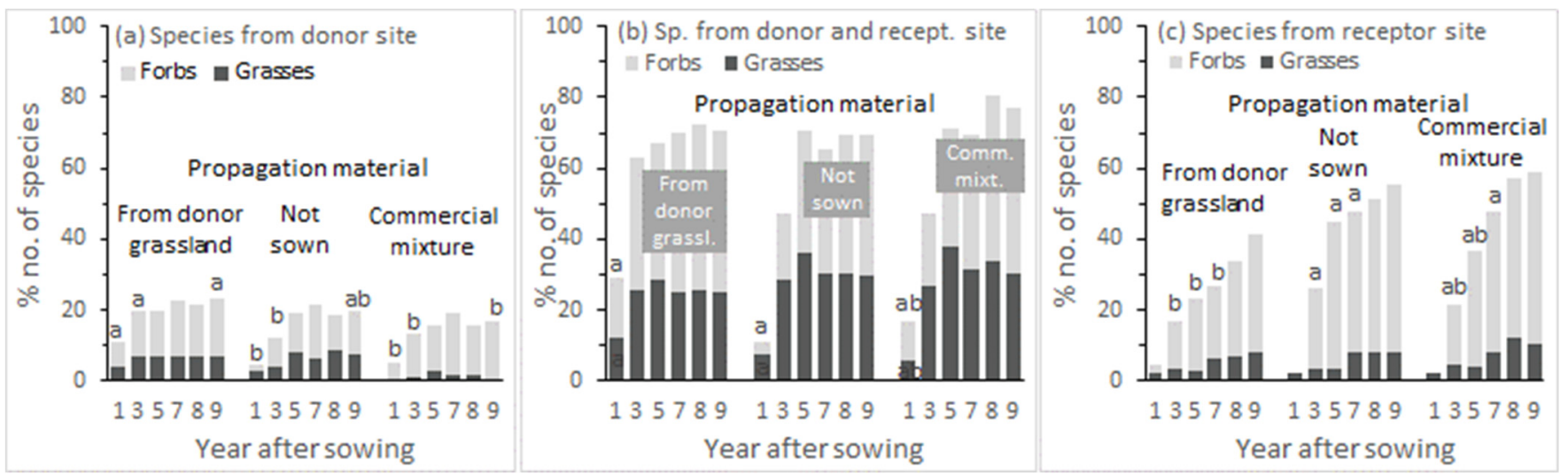

Figure 3. Time pattern of the percent number of species (total, grasses, and forbs) (a) from the donor site grassland (Nardo-Agrostion), (b) from both the donor and receptor site, and (c) only from the receptor site established in $25 \mathrm{~m}^{2}$ plots of a ski slope grassland restoration experiment. The total species numbers were 42 in (a), 24 in (b), and 48 in (c). In each graph, letters above the bars show the result of the among-propagation material comparison separately for each year. Means with common letters do not differ at $p \leq 0.05$. 


\subsection{Species Transfer}

In the nine-year period, the absolute transfer rate was $67.9 \%$ (38 out of the 56 donor site species were found at least once in the experimental plots), with a final value of $52 \%$ (29 species). The relative transfer rate was $89 \%$, with a final value of $74 \%$ (not shown).

In the treatments with donor grassland materials, most D or DRn species were established in the first three years, and only a few of them (exclusively forbs) were established in subsequent years (Figure $3 a, b$ ). D species were also found in the $\mathrm{N}$ and $\mathrm{C}$ treatments (Figure 3a), but they were established later than in the treatments with donor grassland materials.

In the nine-year period, the number of species surveyed in the receptor site vegetation and found at least once in the experimental plots sown with any propagation material was 70 ( $97 \%$ of the total number of receptor site species). The DRn species were established in the same amount in the different propagation material treatments, except for in the first year after sowing, when a higher amount was found in the treatments with donor grassland material (Figure $3 b$ ). Until the seventh year, the Ro species colonising the experimental plots were more numerous in the $\mathrm{N}$ and $\mathrm{C}$ treatments than in the treatments with donor grassland materials (Figure 3c). The difference persisted in subsequent years, even if it was no longer significant. Grasses established especially in the first seven years, whereas forbs were established in subsequent years as well (Figure 3c). As the seed harvesting at the donor site was performed at the stage of optimal grass seed maturation, the percentage of donor site grasses transferred to the receptor site was considerably higher than the percentage of transferred donor site forbs (Figure $3 a, b$ ). Contrasting this, grasses and forbs of the surrounding vegetation were found in the restored plots at the same percentage as in the source vegetation (Figure 3c).

No relationship was found between the cover species number, transfer traits, and the yearly meteorological data.

\subsection{Species Composition}

The species composition was significantly affected by all experimental factors. Year had the highest effect, explaining $16.8 \%$ of the total variance ('Trace' in Table 3). The type of propagation material had an intermediate effect and fertilisation had the lowest effect ( $14.2 \%$ and $1 \%$ of the variance explained, respectively).

Table 3. Effect of six propagation materials, two fertilisation treatments, and years on the species composition (presenceabsence data) and vegetation structure (cover data) in a ski slope grassland restoration experiment calculated in RDA analyses. Plot is a dummy variable used to define individual experimental plots.

\begin{tabular}{|c|c|c|c|c|c|}
\hline Analysis & Explanatory Variable & Covariable & Trace & $F_{\text {trace }}$ & $p$ \\
\hline \multirow{4}{*}{$\begin{array}{l}\text { Species composition } \\
\text { (presence-absence) }\end{array}$} & Treatment & Year, Block & 0.183 & 5.3 & 0.001 \\
\hline & Propagation material & Year, Fertilisation, Block & 0.142 & 8.8 & 0.001 \\
\hline & Fertilisation & Year, PropMaterial, Block & 0.009 & 2.9 & 0.026 \\
\hline & Year & Plot, Block & 0.168 & 12.7 & 0.001 \\
\hline \multirow{6}{*}{$\begin{array}{l}\text { Vegetation structure } \\
\text { (\% cover })\end{array}$} & Treatment $\times$ Year & Year, Plot, Block & 0.165 & 1.2 & 0.001 \\
\hline & Treatment & Year, Block & 0.213 & 8.4 & 0.001 \\
\hline & Propagation material & Year, Fertilisation, Block & 0.185 & 15.7 & 0.001 \\
\hline & Fertilisation & Year, PropMaterial, Block & 0.007 & 3.0 & 0.1708 \\
\hline & Year & Plot, Block & 0.28 & 30.9 & 0.001 \\
\hline & Treatment $\times$ Year & Year, Plot, Block & 0.151 & 2.0 & 0.001 \\
\hline
\end{tabular}

The first two components of the PCA obtained from the presence-absence data (Figure 4a) showed two main gradients. The 20 treatments were arranged along the first component (horizontal axis), with first year samples at the right side, last year samples at the left side, and intermediate years samples in intermediate positions. The change in species composition (movement along the axis from the right to the left side) is distinctly marked between the first and the third year and less marked in the following years. The 
second component (vertical axis) shows the donor grassland at lower values and the receptor site vegetation at higher values. Along the second component, the $\mathrm{N}$ and $\mathrm{C}$ plots are arranged closer to the receptor site vegetation, and the G, g, D, and S plots are closer to the donor grassland. Fertilisation did not appear to influence the sample position on the first two axes.
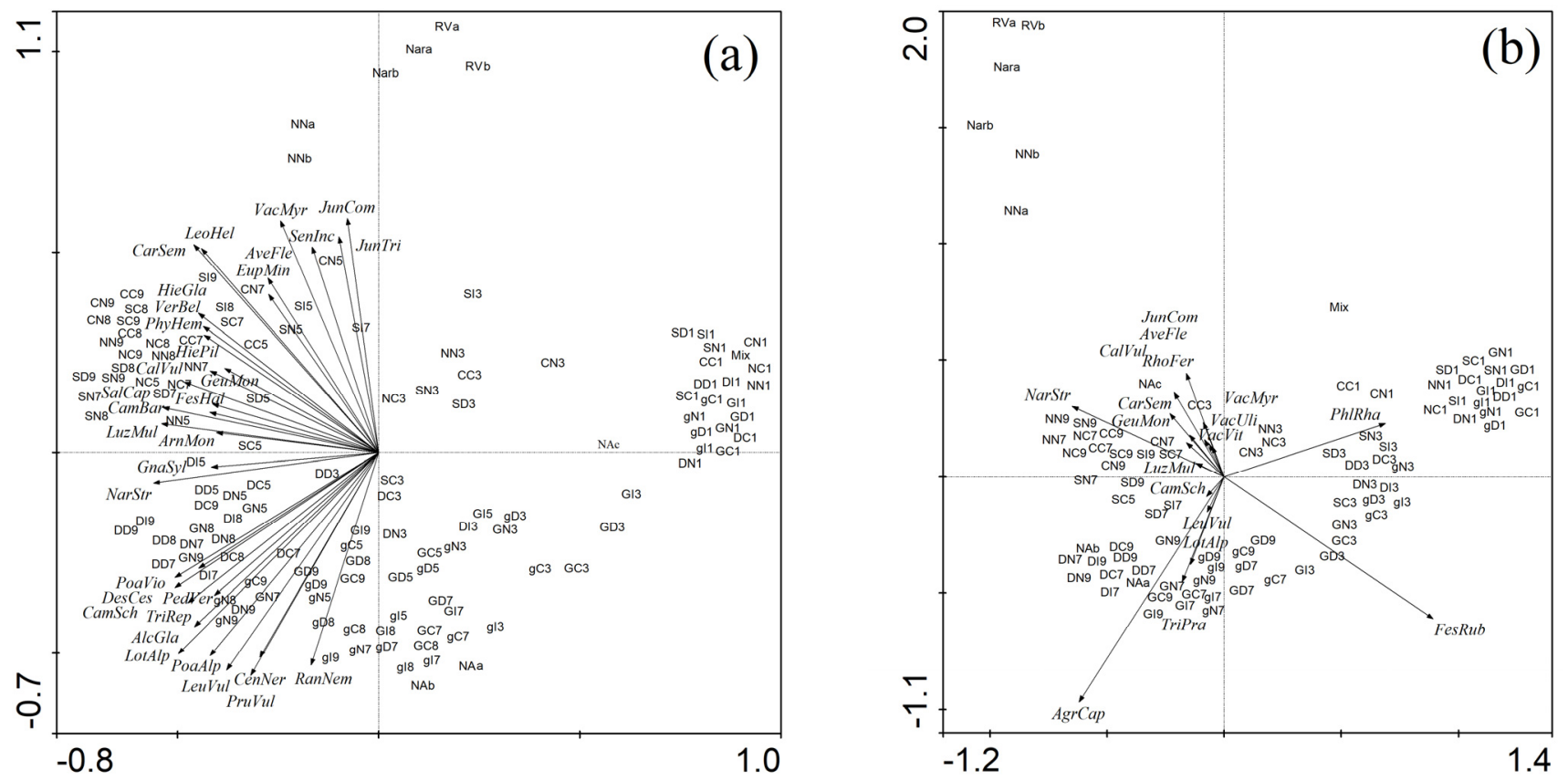

Figure 4. PCA sample-species biplots showing (a) the species composition (presence-absence data) and (b) vegetation structure (\% cover data) of 128 treatments from a ski slope grassland restoration experiment. Codes of the experimental treatments are as follows: first character, G, g, S, D, N, and C, type of propagation material (see legend of Table 2); second character, C, I, D, and N, continuous, initial, delayed and no fertilisation, respectively; third character, 1, 3, 5, 7, 8, and 9, year after sowing. Further, samples of the donor grassland and receptor site vegetation are shown with codes as follows: NAaNAc, Nardo-Agrostion donor grassland; Nara and Narb, Nardion strictae receptor site grassland; RVa and RVb, Rhododendro ferruginei-Vaccinion myrtilli vegetation; $\mathrm{NNa}$ and $\mathrm{NNb}$, non-sown ski slope vegetation. Species codes are composed of the first three letters of genus name and species epithet (see Table S3). Species variances are explained by principal components 1 and 2: $21 \%$ and $10 \%$ in (a), and $31 \%$ and $20 \%$ in (b). Scaling of ordination scores focused on inter-sample distances. Species shown were selected according to the species fit criterion. For simplicity, in graph (b) only samples of years 1, 3, 7, and 9 after sowing are shown (samples from years 5 and 8 are intermediate between the previous and following year).

The species group shown in the low-left part of the PCA graph included plants (e.g., Alchemilla glabra and Lotus alpinus) surveyed in the donor grassland and efficiently transferred to the experimental plots with donor grassland materials. The group in the left-high graph part included only Ro species (e.g., Vaccinium myrtillus, and Leontodon helveticus) or DRn species (e.g., Nardus stricta, and Luzula multiflora), which were able to colonise especially the $\mathrm{N}$ and $\mathrm{C}$ plots. Some very frequent $\mathrm{DRn}$ species (e.g., Festuca rubra and Agrostis capillaris) or Ro species (e.g., Agrostis rupestris) were not selected, as they were present in all samples (Table S3); therefore, they were unable to significantly characterise the sample placement in the PCA space. Among species in the cultivar mixture, only Festuca rubra and Trifolium repens were frequently found in all survey years and treatments.

\subsection{Vegetation Structure}

The vegetation structure was significantly affected by all experimental factors with the same ranking as observed for the species composition, namely, year, propagation material, and fertilisation (Table 3). The main and interaction effects of the three factors together explained $64 \%$ of the variance, i.e., $12 \%$ more than in the case of species composition. The 
PCA graph based on cover data (Figure $4 b$ ) showed a vegetation pattern that was not very dissimilar from the species composition. The first component represented the pattern of the structural change during the nine years (initial years on the right and final years on the left). The second axis represented the contrast between the donor (below) and the receptor (above) site vegetation. Treatments sown with donor grassland materials were closer to donor grassland vegetation; $\mathrm{N}$ and $\mathrm{C}$ treatments were closer to the receptor site vegetation.

The main species characterising the time pattern of the vegetation structure were the grasses (Table S3). Phleum rhaeticum, Festuca rubra, and Agrostis tenuis, which were the species abundant in both the donor and receptor site vegetation, were present in all experimental treatments and years. However, the abundance of Phleum rhaeticum was high in the first year (average 9\%) and decreased subsequently (0-3\%). Festuca rubra established rapidly and attained very high abundances in the first three years (40-54\%) but decreased subsequently, even while maintaining a high cover (23-33\%). Agrostis tenuis was established slowly: its cover was low (1-2\%) in the first three years but increased in the following years to $3-8 \%$. Nardus stricta, a species very abundant in the receptor site vegetation, was able to establish, especially in the $\mathrm{N}$ and $\mathrm{C}$ treatments, where it attained a cover of about $4 \%$ from the fifth year onwards.

\section{Discussion}

\subsection{Ground Cover}

Regardless of fertilisation and propagation material, at the experimental site, located in the low-alpine belt on a very gravelly soil, the plant cover was not full even nine years after revegetation. This result fits well with previous findings from graded ski slopes in siliceous Alps [37]. According to Felber et al. [2], the lack of success in partial revegetation in the range from 1500 to $200 \mathrm{~m}$ over the tree line is usually due to difficult soil conditions (especially more than $70 \%$ gravel in the soil), while at higher altitudes, the cold climate would be the main reason. In fact, the high gravel soil content was probably the main factor for the incomplete plant cover achieved, as demonstrated by the full vegetation cover observed at nearby graded slopes where topsoil had been stored and re-used. The percentage of unvegetated ground was partially occupied by BSC (9.4\% in the ninth year). Even if BSC is a symptom of unfavourable site conditions, it plays an important role in soil stabilisation, moisture conservation, and nitrogen and organic matter enrichment [38,39].

The lack of evidence of soil erosion during the survey period was due to several factors. In the first year, the plant cover was less than the $70 \%$ threshold under which significant erosion can occur [37], but the soil was protected by the hay or straw mulching. In the following years, vascular plants plus BSC plus stones $>5 \mathrm{~cm}$ covered more than $80 \%$ of the ground and prevented any significant erosion.

Fertilisation affected the plant cover more than the propagation material. The effect was high (about 20\%) in the four initial years when fertilisers were supplied but decreased to being no more significant in the years after fertilisation cessation. This early but transient effect was often found in revegetation experiments on raw soils $[37,40]$ and is likely due to the high soil gravel content. Even if phosphorous and potassium initially supplied with fertilisers can persist in the soil, the supplied nitrogen is rapidly lost by leaching in loose soils, and the introduction of $\mathrm{N}$-fixing species is a better strategy to stably improve the $\mathrm{N}$ soil fertility $[37,41]$.

As in the case of fertilisation, the propagation material effect on the plant cover was high in the initial years but low later. This result is surprising as the two treatments were sowing with site-unsuited commercial cultivars and no sowing at all. In fact, the behaviours of the propagation materials were very different. All donor grassland materials proved site-adapted and created a persisting plant cover, as often found for well-selected native materials introduced to difficult sites (e.g., [42-44]). The variable sowing rate (G vs. g) had no effect on the ground cover, as it was always higher than that needed to obtain a full plant cover [43]. In contrast, in the $C$ treatment, most cultivars did not establish or rapidly disappeared because of the difficult site conditions $[10,40]$, and the final high plant cover 
was due to the area left free by cultivars being occupied by native species. The same species were equally able to colonise the $\mathrm{N}$ plots. This aspect will be discussed later in this paper.

\subsection{Species Number}

The average species number was 21 , but 28 in the last surveyed year, i.e., only one less than the species richness of the surrounding vegetation. This richness is similar to that found 4-40 years after revegetation on graded slopes in the Alps subalpine-alpine zone (34 species in Klug-Pümpel and Krampitz [45]; 29 species in Roux-Fouillet et al. [14]; 25 species in Hudek et al. [17].

Fertilisation had a small negative effect on species richness (-1.5). A similar effect was observed in other high-altitude revegetation and is probably due to fertilisers increasing the grass growth, thereby reducing the number of safe sites available for other species [7]. In the Tognola experiment, this result was probably due to the higher cover of the main grass, Festuca rubra. The effect increased in the fertilising period but was present later as well, along with the persistent higher grass cover.

The propagation material had no effect on the total number of species. This result is not surprising with regard to the comparison among the donor grassland materials and confirms the results by Scotton [22,43]. However, it is surprising with regard to the comparison between the donor grassland materials and the $C$ treatment, which was sown with much fewer species (27 vs. 11) and the $\mathrm{N}$ treatment, which was not sown at all. However, even if there was no effect on the total species number, the number of species with different origins was considerably influenced. In $\mathrm{C}$ and $\mathrm{N}$, the initial lower species richness was rapidly compensated for by plant colonisation from the surrounding vegetation. In $\mathrm{C}$, this was possible, as most sown cultivars had low persistence. Moreover, in the $\mathrm{C}$ and $\mathrm{N}$ treatments, the initially higher availability of unvegetated ground resulted in a more efficient colonisation from the surrounding vegetation and a higher species number in the last surveyed year. A lower abundance of grasses (especially Festuca rubra) in $\mathrm{C}$ and $\mathrm{N}$ contributed strongly to this result. Therefore, unlike what was found at more favourable low-altitude sites (e.g., $[46,47])$, forage cultivars neither competed with native species nor hindered their colonisation.

\subsection{Species Transfer}

Except for the commercial mixture, species from all other origins showed efficient establishment and spreading at the experimental site. Many native species introduced as mature seeds from the donor grassland were observed at least once during the survey period (relative transfer rate $89 \%$ ). This result is comparable with values obtained in grasslands restored on bare soils with fresh hay at lower altitudes $(80-96 \%$, [32]; 81-98\%, [22,43]. As found in Scotton [22,43], the establishment of species present in the donor grassland materials occurred only in the first three years after restoration. However, most species transferred were able to colonise the $\mathrm{N}$ and $\mathrm{C}$ plots in the following years, showing a higher ability to reach the close plots than observed in other low-altitude experiments (e.g., [48]).

Seventy out of 72 species surveyed in the surrounding vegetation were able to colonise the experimental plots. The colonisation was more intense in the initial years but was very active subsequently as well. The unvegetated ground available resulted in an earlier and stronger establishment of these species in the $\mathrm{N}$ and $\mathrm{C}$ plots than in the treatments with donor grassland materials, and the difference persisted throughout the survey period.

The high potential for species mobility and establishment observed was probably a consequence of some concomitant favourable factors. At the restoration site, the surrounding vegetation was very close to the experimental plots (mean distance 15-20 m). In spontaneously revegetating gravel-sand pits, ̌̌ehounková and Prach [49] found that nearly $75 \%$ of grassland species occurring within a $100 \mathrm{~m}$ distance appeared in the pits. In high-altitude graded ski runs, Urbanska [7] found that only species within a maximum distance of $15 \mathrm{~m}$ efficiently colonised the ski slope 9-10 years after grading. On the contrary, when the surrounding grasslands were far from the revegetation site, no or very poor 
plant colonisation was observed, as was found at waste heaps [8,11,15], ski slopes [4], and ex-quarries [43].

A second favourable factor was that in all plots, the plant cover increased slowly and was not fully even in the ninth year, owing to the difficult soil and climate conditions. Similarly, a loose, low-growing grassland was the best condition for an effective colonisation of volunteer species in the graded ski slopes studied by Felber et al. [2]. Competition is likely to have little effect in the initial stages of plant establishment [50]. In addition, at high elevations where abiotic stress is high and plant growth is poor, the interactions among plant species are mostly positive [51].

\subsection{Species Composition and Vegetation Structure}

Regardless of the fertilisation treatment, the species composition became progressively more similar to both the donor grassland and the receptor site Nardion grassland. This was possible because the donor and receptor sites had many species in common. However, while the trend of increasing similarity towards the donor grassland observed in the treatments with donor grassland material plateaued in the second half of the survey period, increasing similarity towards the receptor site Nardion grassland persisted in the final years, especially in the $\mathrm{N}$ and $\mathrm{C}$ treatments. This difference was due to the fact that species from the donor grassland were introduced only once at the sowing time, while the receptor site vegetation represented a continuous seed source of potential plant colonisers. Similar trends of restored vegetation progressively approaching the receptor site vegetation were found by Klug-Pümpel and Krampitz [45] and Hudek et al. [17] at graded slopes where the surrounding grasslands were close to the restored area.

Grasses were the main species established in all the experimental plots. In the initial years, they were nearly exclusive components of the plant cover, but their contribution remained very high later. The initial grass predominance is often observed in grassland restoration (e.g., [22,52]) and is usually explained based on efficient vegetative spreading via tillering [53].

Native DRn grasses with the highest establishment were Festuca rubra and Agrostis tenuis, the first species since the beginning and the second one since the fifth year after sowing. Both species are particularly well adapted to acidic soils and high altitudes [54], where they are often successfully used for revegetation (e.g., [8,15]). For Festuca rubra cultivars, a facilitation effect of native plant colonisation was sometimes observed [10], while other studies found an opposite effect (e.g., [55]). A negative relationship between species cover and plant richness was also observed in this study. However, the species abundance did not prevent colonisation by the receptor site species, indicating that its native forms are probably less competitive than commercial cultivars [55].

Except for the Festuca rubra cultivars, only Phleum pratense among the other grass cultivars was initially able to reach a high cover (20-30\%). Its abundance was particularly high in fertilised treatments, as expected based on its competitive habit [56]. Phleum pratense was often observed to create high cover at subalpine restored sites, thereby preventing native plant colonisation [57]. However, this effect was not observed in this experiment because the species did not persist beyond the fifth year because of their poor adaptation to the harsh climate [45]. The cold climate was probably the reason why the cultivars of the other grasses failed to establish.

Many grasses from the surrounding vegetation colonised all experimental plots, especially in the $\mathrm{N}$ and $\mathrm{C}$ treatments. Among them, Nardus stricta was characteristic of the well-developed soil Nardion grassland, but the other species (Festuca helleri, Poa violacea, and Agrostis rupestris) were typical of rocky soils or screes. Similar results were obtained by Delarze [9] and Klug-Pümpel and Krampitz [45] in the low-alpine belt at calcareous and siliceous substrata, respectively. The colonisation ability of these rock-soil or scree species is explained by their preferred natural habitat being very similar to the shallow, gravelly soils of the graded ski runs. This was also demonstrated by their frequency increasing even 
in the last surveyed years, when the unvegetated portion of the restored plots was mostly occupied by stones.

Forbs and dwarf shrubs were established later than grasses, but their number and abundance became increasingly important in the last surveyed years. These species originated mainly from the surrounding vegetation and were also mostly typical of rocky soils and screes (e.g., Hieracium glanduliferum and Centaurea nervosa).

\section{Practical Implications for Ski Slope Revegetation}

At high altitudes (vegetative period shorter than 100 days), topsoil storage and reusing is a necessary condition for revegetation to achieve a full cover of native species. For sites where this was not done but the soil conditions are not prohibitive (gravel content less than $70 \%$ ) and natural grasslands surround the restoration site, the following suggestions can be made:

1. Using propagation material from (semi-)natural grasslands with climate and soil similar to the restoration site: any material type performs well.

2. If native propagation material is unavailable, adopting seed mixtures of short-lived cultivars can create an initial but non-persistent plant cover.

3. Retaining nearby pre-existing vegetation as intact as possible, as it is an efficient seed source for colonising native species.

4. Limiting fertilisation to the first year, as it reduces the number of colonising species and has a transient effect on the plant cover. The anti-erosion effect of the rapid achievement of a full plant cover aimed at with fertilisation can be replaced by organic mulching. If necessary, only phosphorous and potassium can be applied, as they are not leached and favour the establishment of $\mathrm{N}$-fixing species, which can naturally increase the soil nitrogen fertility.

\section{Conclusions}

At the experimental site, slope grading without topsoil storage and reuse created raw substrata with high gravel content and many stones on the soil surface, which prevented the establishment of a full vegetation cover in the middle term.

However, in the experimental soil (gravel content less than 70\%), an efficient antierosion native plant cover was achieved due to two main reasons. Firstly, the native propagation materials used were collected from a semi-natural grassland with climate and soil similar to the restored site and with many species in common with the vegetation surrounding the restoration site. Secondly, the species of the donor and receptor sites demonstrated a significant ability to spread and colonise nearby areas. Under these conditions, even $\mathrm{C}$ and $\mathrm{N}$ plots were easily colonised by volunteer species, thereby achieving high plant cover.

Instead, due to the gravelly soil and poor plant growth caused by the harsh climate, fertilisation had only a transient effect on the plant cover and a null effect on the species composition.

Supplementary Materials: Supplementary Tables S1-S4 and Figures S1 and S2 can be found online at https:/ / www.mdpi.com/article/10.3390/agriculture11050381/s1. Figure S1: Relationship between Festuca rubra cover and total number of species of the vegetation obtained with four types of propagation material from a Nardo-Agrostion donor grassland and four fertilisation levels at a ski slope grassland restoration experiment. Data refer to 7-11 years after sowing, Figure S2: Time pattern of the vascular plant cover and number at a ski slope grassland restoration experiment. Data show the results from four treatments obtained by combining two propagation materials $(\mathrm{N}$, no sowing; C, cultivar mixture) combined with two fertilisation levels (with, CF, and without, NF, fertilisation in the first four years after sowing). Letters show results of among-treatment comparisons within each year. Means with common letters do not differ at $p \leq 0.05$. Missing letters means not significant treatment effect. Table S1: Total rainfall and mean temperature recorded in the experimental years at the reference weather station of Passo Rolle (2004 m a.s.1.), Table S2: Soil characteristics of the experimental area, the surrounding vegetation, and the donor site of the ski slope restoration experiment 
(soil layer 0-10 cm). na means not available, Table S3: Species composition of 120 surveys from a grassland restoration experiment at a raw soil ski slope (percent ground cover as average of three replications). Ten surveys from donor and receptor site vegetation and species composition of the cultivar seed mixture are also included. Surveys were clustered with the van der Maarel coefficient as similarity function and the minimum variance as clustering method: species were clustered with the Pearson correlation coefficient and the average linkage (Legendre and Legendre, 2012). Before clustering, cover data were transformed according to the 1-9 scale of Maarel (1979) to reduce the importance of the most abundant species, Table S4: Effect of four propagation materials and four fertilisation treatments on the main traits of a ski slope grassland restoration experiment.

Funding: The study was funded by the Natural Park Paneveggio-Pale di San Martino (project Ski slopes restoration) and the European Union (European Territorial Cooperation Programme CENTRAL EUROPE 2007-2013, project 1CE052P3 SALVERE).

Data Availability Statement: The data are included in the Supplementary Materials.

Acknowledgments: I thank Lisa Piccinin and Antonio Timoni for their field surveys. I am also grateful to the ski area company, Funivie Seggiovie San Martino S.r.l., for willingly permitting and hosting the research.

Conflicts of Interest: The author declares no conflict of interest.

\section{References}

1. Vanat, L. International Report on Snow \& Mountain Tourism: Overview of the Key Industry Figures for Ski Resorts, 12th edition, 2020. Available online: http:/ / www.vanat.ch/RM-world-report-2020.pdf (accessed on 13 February 2021).

2. Felber, H.U.; Hirsch, M.; Walther, P. Landschaftseingrifffe für den Skisport: Wegleitung zur Berücksichtigung des Natur- und Landschaftsschutzes; Eidgenossische Departement des Innern: Bern, Switzerland, 1991.

3. Pintaldi, E.; Hudek, C.; Stanchi, S.; Spiegelberger, T.; Rivella, E.; Freppaz, M. Sustainable soil management in ski areas: Threats and challenges. Sustainability 2017, 9, 2150. [CrossRef]

4. Burt, J.W.; Rice, K.J. Not all ski slopes are created equal: Disturbance intensity affects ecosystem properties. Ecol. Appl. 2009, 19, 2242-2253. [CrossRef]

5. Forbes, B.C.; Jefferies, R.L. Revegetation of disturbed arctic sites: Constraints and applications. Biol. Conserv. 1999, 88, 15-24. [CrossRef]

6. Barni, E.; Freppaz, M.; Siniscalco, C. Interactions between Vegetation, Roots, and Soil Stability in Restored High-altitude Ski Runs in the Alps. Arct. Antarct. Alp. Res. 2007, 39, 25-33. [CrossRef]

7. Urbanska, K.M. Restoration ecology research above the timberline: Colonization of safety islands on a machine-graded alpine ski run. Biodivers. Conserv. 1997, 6, 1655-1670. [CrossRef]

8. Rydgren, K.; Auestad, I.; Hamre, L.N.; Hagen, D.; Rosef, L.; Skjerdal, G. Long-term persistence of seeded grass species: An unwanted side effect of ecological restoration. Environ. Sci. Pollut. Res. 2016, 23, 13591-13597. [CrossRef]

9. Delarze, R. Dynamique de la vegetation sur les pistes ensemencees de Crans-Montana (Valais, Suisse). Effets de l'altitude. Botanica Helvetica 1994, 104, 3-16.

10. Gretarsdottir, J.; Aradottir, A.L.; Vandvik, V.; Heegaard, E.; Birks, H.J.B. Long-term effects of reclamation treatments on plant succession in Iceland. Restor. Ecol. 2004, 12, 268-278. [CrossRef]

11. Ash, H.J.; Gemmell, R.P.; Bradshaw, A.D. The introduction of native plant species on industrial waste heaps: A test of immigration and other factors affecting primary succession. J. Appl. Ecol. 1994, 31, 74-84. [CrossRef]

12. Krautzer, B.; Wittmann, H.; Peratoner, G.; Graiss, W.; Partl, C.; Parente, G.; Venerus, S.; Rixen, C.; Streit, M. Site-Specific High Zone Restoration in the Alpine Region: The Current Technological Development; HBLFA Raumberg-Gumpenstein: Irdning, Austria, 2006.

13. Argenti, G.; Ferrari, L. Plant cover evolution and naturalisation of revegetated ski runs in an Apennine ski resort (Italy). iForest 2009, 2, 178-182. [CrossRef]

14. Roux-Fouillet, P.; Wipf, S.; Rixen, C. Long-term impacts of ski piste management on alpine vegetation and soils. J. Appl. Ecol. 2011, 48, 906-915. [CrossRef]

15. Rydgren, K.; Halvorsen, R.; Odland, A.; Skjerdal, G. Restoration of alpine spoil heaps: Successional rates predict vegetation recovery in 50 years. Ecol. Eng. 2011, 37, 294-301. [CrossRef]

16. Skeffington, R.A.; Bradshaw, A.D. Nitrogen fixation by plants growing on reclaimed China clay wastes. J. Appl. Ecol. 1980, 17, 469-477. [CrossRef]

17. Hudek, C.; Barni, E.; Stanchi, S.; D’Amico, M.; Pintaldi, E.; Freppaz, M. Mid and long-term ecological impacts of ski run construction: On alpine ecosystems. Sci. Rep. 2020, 10, 11654. [CrossRef] [PubMed]

18. OFP (Office Federal des Forets et de la Protection du Paysage). Directives Concernant les Atteintes Portees au Paysage dans l'Interet du Ski; OFCIM: Bern, Switzerland, 1979. 
19. Feucht, B.; Rieger, E.; Tamegger, C.; Jahn, F.; Jongepierová, I. Agricultural production of seeds from regional provenance. In Practical Handbook for Seed Harvest and Ecological Restoration of Species-Rich Grasslands; Scotton, M., Kirmer, A., Krautzer, B., Eds.; CLEUP: Padova, Italy, 2012; pp. 33-38.

20. Scotton, M.; Rieger, E.; Feucht, B.; Tamegger, C.; Jahn, F.; Ševčíková, M.; Semanová, I.; Krautzer, B.; Graiss, W.; Haslgrübler, P.; et al. Techniques for harvesting seeds and plant material in species-rich grasslands. In Practical Handbook for Seed Harvest and Ecological Restoration of Species-Rich Grasslands; Scotton, M., Kirmer, A., Krautzer, B., Eds.; CLEUP: Padova, Italy, 2012.

21. Malaval, S.; Dupin, B.; Dantin, G. Conservation et restauration de la flore dans un contexte anthropisé, quelles solutions? Sci. Eaux Territ. 2015, 16, 70-75. [CrossRef]

22. Scotton, M. Establishing a semi-natural grassland: Effects of harvesting time and sowing density on species composition and structure of a restored Arrhenatherum elatius meadow. Agric. Ecosyst. Environ. 2016, 220, 35-44. [CrossRef]

23. Locher, O.N.; Streit, M.; Frei, M.; Andrey, C.; Blaser, R.; Meyer, J.; Muller, U.; Reidy, B.; Rixen, C.; Schutz, M. Linee Guida per Il Rinverdimento ad Alta Quota; Verein für Ingenieurbiologie: Wädenswil, Switzerland, 2008.

24. Rubel, F.; Brugger, K.; Haslinger, K.; Auer, I. The climate of the European Alps: Shift of very high resolution Köppen-Geiger climate zones 1800-2100. Climatology 2017, 26, 115-125. [CrossRef]

25. Theurillat, J.-P.; Aeschimann, D.; Küpfer, P.; Spichiger, R. The higher vegetation units of the Alps. Colloques Phytosociologiques 1995, 23, 189-239.

26. Pignatti, S. Flora d'Italia; Edagricole: Bologna, Italy, 1982.

27. Scotton, M.; Piccinin, L.; Dainese, M.; Sancin, F. Seed harvesting for ecological restoration: Efficiency of haymaking and seed-stripping on different grassland types in the eastern Italian Alps. Ecol. Restor. 2009, 27, 66-75. [CrossRef]

28. Schiechtl, H.M. Bioengineering for Land Reclamation and Conservation; University of Alberta Press: Edmonton, AB, Canada, 1980.

29. Legendre, P.; Legendre, L. Numerical Ecology, 3rd ed.; Elsevier Science BV: Amsterdam, The Netherlands, 2012.

30. Van der Maarel, E. Transformation of cover-abundance values in phytosociology and its effects on community similarity. Vegetatio 1979, 39, 97-114.

31. Quinn, G.P.; Keough, M.J. Experimental Design and Data Analysis for Biologists; Cambridge University Press: Cambridge, UK, 2002.

32. Kiehl, K.; Kirmer, A.; Donath, T.W.; Rasran, L.; Hölzel, N. Species introduction in restoration projects-Evaluation of different techniques for the establishment of semi-natural grasslands in Central and Northwestern Europe. Basic Appl. Ecol. 2010, 11, 285-299. [CrossRef]

33. Rosenweig, M. Species Diversity in Space and Time; Cambridge University Press: Cambridge, UK, 1995.

34. SAS Institute Inc. SAS/STAT®13.2.; SAS Institute Inc.: Cary, NC, USA, 2002-2012.

35. Leps, J.; Šmilauer, P. Multivariate Analysis of Ecological Data Using CANOCO; Cambridge University Press: Cambridge, UK, 2003.

36. Wildi, O.; Orloci, L. Numerical Exploration of Community Patterns; SPB Academic Publishing: The Hague, The Netherlands, 1990.

37. Mosimann, T. Das Stabilitätspotential alpiner Geoökosysteme gegenüber Bodenstörungen durch Skipistenbau. Verhandlungen Gesellschaft Ökologie 1984, 12, 167-176.

38. Belnap, J.; Kaltenecker, J.H.; Rosentreter, R.; Williams, J.; Leonard, S.; Eldridge, D. Biological Soil Crusts: Ecology and Management; United States Department of the Interior, Bureau of Land Management: Denver, CO, USA, 2001.

39. Elmarsdottir, A.; Aradottir, A.L.; Trlica, M.J. Microsite availability and establishment of native species on degraded and reclaimed sites. J. Appl. Ecol. 2003, 40, 815-823. [CrossRef]

40. Petersen, S.L.; Roundy, B.A.; Bryant, R.M. Revegetation Methods for High-Elevation Roadsides at Bryce Canyon National Park, Utah. Restor. Ecol. 2004, 12, 248-257. [CrossRef]

41. Bradshaw, A. Restoration of mined lands-Using natural processes. Ecol. Eng. 1997, 8, 255-269. [CrossRef]

42. Tinsley, M.J.; Simmons, M.T.; Windhager, S. The establishment of native versus non-native herbaceous seed mixes on a revegetated roadside in Central Texas. Ecol. Eng. 2006, 26, 231-240. [CrossRef]

43. Scotton, M. Calcareous grassland restoration at a coarse quarry waste dump in the Italian Alps. Ecol. Eng. 2018, 117, 174-181. [CrossRef]

44. Gentili, R.; Casati, E.; Ferrario, A.; Monti, A.; Montagnani, C.; Caronni, S.; Citterio, S. Vegetation cover and biodiversity levels are driven by backfilling material in quarry restoration. Catena 2020, 195, 104839. [CrossRef]

45. Klug-Pümpel, B.; Krampitz, C. Conservation in Alpine Ecosystems: The plant cover of ski runs reflects natura1 as well as anthropogenic environmental factors. Die Bodenkultur 1996, 47, 97-117.

46. Conrad, M.K.; Tischew, S. Grassland restoration in practice: Do we achieve the targets? A case study from SaxonyAnhalt/Germany. Ecol. Eng. 2011, 37, 1149-1157. [CrossRef]

47. Brenner, F.J.; Werner, M.; Pike, J. Ecosystem development and natural succession in surface coal mine reclamation. Min. Environ. 1984, 6, 10-22. [CrossRef]

48. Baasch, A.; Engst, K.; Schmiede, R.; May, K.; Tischew, S. Enhancing success in grassland restoration by adding regionally propagated target species. Ecol. Eng. 2016, 94, 583-591. [CrossRef]

49. Řehounková, K.; Prach, K. Spontaneous vegetation succession in gravel-sand pits: A potential for restoration. Restor. Ecol. 2007, 16, 305-312. [CrossRef]

50. Grime, J.P. Competitive exclusion $m$ herbaceous vegetation. Nature 1973, 242, 344-347. [CrossRef]

51. Callaway, R.M.; Brooker, R.W.; Choler, P.; Kikvidze, Z.; Lortie, C.J.; Michalet, R.; Paolini, L.; Pugnaire, F.L.; Newingham, B.; Aschehoug, E.T.; et al. Positive interactions among alpine plants increase with stress. Nature 2002, 417, 844-848. [CrossRef] 
52. Pywell, R.F.; Bullock, J.M.; Roy, D.B.; Warman, L.; Walker, K.J.; Rothery, P. Plant traits as predictors of performance in ecological restoration. J. Appl. Ecol. 2003, 40, 65-77. [CrossRef]

53. Thormann, A.; Kiehl, K.; Pfadenhauer, J. Einfluss unterschiedlicher Renaturierungsmaßnahmen auf die langfristige Vegetationsentwicklung neu angelegter Kalkmagerrasen. Angewandte Landschaftsökologie 2003, 55, 73-106.

54. Landolt, E.; Bäumler, B.; Erhardt, A.; Hegg, O.; Klötzli, F.; Lämmler, W.; Nobis, M.; Rudmann-Maurer, K.; Schweingruber, F.H.; Theurillat, J.-P.; et al. Flora indicativa. Ökologische Zeigerwerte und Biologische Kennzeichen zur Flora der Schweiz und der Alpen. Ecological Indicator Values and Biological Attributes of the Flora of Switzerland and the Alps; Haupt Verlag AG.: Bern, Switzerland, 2010.

55. Hagen, D.; Hansen, T.I.; Graae, B.J.; Rydgren, K. To seed or not to seed in alpine restoration: Introduced grass species outcompete rather than facilitate native species. Ecol. Eng. 2014, 64, 255-261. [CrossRef]

56. Isselin-Nondedeu, F.; Bédécarrats, A. Assessing the dominance of Phleum pratense cv. climax, a species commonly used for ski trail restoration. Appl. Veg. Sci. 2009, 12, 155-165. [CrossRef]

57. Höglind, M.; Schapendonk, A.H.C.M.; van Oijen, M. Timothy growth in Scandinavia: Combining quantitative information and simulation modelling. New Phytol. 2001, 151, 355-367. [CrossRef] 